\title{
Indirect infringement
}

\author{
Daniel M. Becker
}

Indirect infringement of intellectual property rights can be found when a party actively induces a third party to infringe a patent, or contributes to that infringement.

US patent law permits claims to be drawn directly to methods of treating the human body and to diagnostic methods practiced on the human body, although both are explicitly proscribed by the European Patent Convention. However, such claims can prove difficult, if not impossible, to enforce against corporate competitors, as the direct infringer of such claims is often a treating physician, a hospital, a potential customer or a patient. To protect such patent rights, the statute explicitly defines two types of indirect infringement, each of which can bestow vicarious liability on a corporate defendant that is not itself a direct infringer of the patent claims.

\section{Prerequisite: direct infringement}

Both types of indirect infringement, contributory infringement and inducement of infringement, require an underlying act of direct infringement by an identified third party.

This requirement can be illustrated by a recent case, Cross Medical Prods. v. Medtronic (Fed. Cir. 2005). To prove either contributory infringement or inducement of infringement of a claim to a spinal fixation device comprising a "bone interface operatively joined to [a] bone segment", the patent owner was obliged to prove that surgeons complete the claimed device by joining the apparatus, as sold, to one or more vertebrae during surgery. (Cross Medical Prods. v. Medtronic; Fed. Cir. 2005). To prove indirect infringement of a method-of-use claim through the sale of a device or a composition, the patent owner must first prove that the device or composition has in fact been used to perform the method.

The scope of the directly infringing acts dictates the scope of indirect infringement: patent owners who identify individual acts of direct infringement must restrict their claims for damages or injunctive relief to such identified acts; patent owners who identify an entire class of direct infringers - such as a defined class of the accused party's customers - can assert their theories of vicarious liability commensurately more broadly.

\section{Knowledge and intent}

Indirect infringement also requires proof of the accused party's state of mind. A contributory infringer must sell, offer to sell, or import a product (that is, a drug or device) with knowledge that its product

\section{BOX | INDUCEMENT BY ANDA}

A generic manufacturer's Abbreviated New Drug Application (ANDA) must include a proposed product label that is limited by law to the FDA-approved indications for the original reference listed drug. When such clinical indication is claimed as a method of treatment in one or more of the innovator's patents listed on the FDA Orange Book, the filing of the ANDA can provide both the jurisdictional and the substantive basis for a claim of inducement of infringement. Indeed, "a patent holder asserting infringement of a patent that claims a FDA-approved method of use for which an ANDA seeks approval will, in many instances, have to prove induced [rather than direct] infringement." Allergan, Inc. v. Alcon Labs., Inc. (Fed. Cir. 2003).

The result is far different, however, when the patented claims are limited to clinical indications that the FDA has never approved:

"Although the FDA had not approved the use of gabapentin for any of the indications claimed in the neurodegenerative method patent, and [rules] forbid the promotion of unapproved uses by NDA or ANDA holders, Warner-Lambert argued that 'patients will use the Apotex Defendants' gabapentin for all purposes for which Warner-Lambert's Neurontin ${ }^{\circledR}$ product has been and customarily is used, and doctors will prescribe the Apotex Defendants' gabapentin product for such uses, including the treatment of neurodegenerative diseases.'... [However, we] conclude that it is not an act of infringement to submit an ANDA for approval to market a drug for a use when neither the drug nor that use is covered by the existing patent, and the patent at issue is for a use not approved under the NDA." Warner-Lambert v. Apotex (Fed. Cir. 2003).

is infringing a patent and knowledge that the product is not 'suitable for substantial non-infringing use.' The case law adds the requirement that the accused party also have knowledge of the asserted patent. The statutory section for contributory infringement excludes from liability the sale, offer or importation of any product that is suitable for non-infringing use; therefore no proof is required that the accused party intended the infringement.

By contrast, no product is excluded from the statutory definition of inducement. On the theory that liability should not be found for the sale of a staple article of commerce based solely on the seller's knowledge that a third party might use the commodity to infringe (for example, based on knowledge that a physician will prescribe an otherwise approved pharmaceutical for an infringing off-label use (see box)) - the courts have imposed a heightened threshold of culpability: the party accused of inducing infringement must be proven to have possessed actual and specific intent to encourage a third party's infringement, and to have acted in furtherance of that intent.

Intent can be demonstrated by circumstantial evidence that the accused knew, or should have known, that its actions would induce actual infringement. For example, "advertising an infringing use or instructing how to engage in an infringing use, show an affirmative intent that the product be used to infringe" (Metro-Goldwyn-Mayer Studios Inc. v. Grokster, Ltd.; Supreme Court, 2005). In a case now headed to the Supreme Court on other grounds, the Court of Appeals for the Federal Circuit found active inducement based on the defendant clinical lab's publications describing and promoting use of the patented diagnostic method (Metabolite Labs., Inc. v. Laboratory Corp. of America; Fed. Cir. 2004). A generic manufacturer's abbreviated New Drug Application (ANDA), by virtue of its very compliance with applicable laws and FDA regulations, might provide such evidence (see BOX).

Daniel M. Becker, M.D., Esq., Dechert LLP, 1117 California Avenue, Palo Alto, California 94304, USA. e-mail:daniel.becker@dechert.com doi: $10.1038 / n r d 1990$ 